\title{
Can you teach old dragons new tricks?
}

\section{FDI and innovation activity in Chinese State-owned enterprises}

\author{
Sourafel Girma, Yundan Gong and Holger Görg \\ University of Nottingham
}

\begin{abstract}
We investigate whether inward FDI, either at the firm or industry level, has any impact on product innovation by Chinese State owned enterprises (SOEs). We use a comprehensive firm level panel data set of Chinese SOEs covering the period 1999 to 2003 . Our results show that foreign capital participation is associated with higher innovative activity. Inward FDI in the sector has a negative effect on innovative activity in SOEs. However, there is a positive effect of FDI on SOEs that export, invest in human capital or R\&D, or have prior innovation experience. We also find that SOEs with internal R\&D activity and human capital development are successful innovators. Hence, our results suggest that rather than relying on sector level inward FDI to improve domestic innovative activity, it is important to get the firm-level fundamentals right.
\end{abstract}

JEL Classification: F23, O31

Keywords: Innovation, FDI, state owned enterprises, spillovers, competition, China

Acknowledgements: Holger Görg gratefully acknowledges financial support from the Leverhulme Trust (Programme Grant F114/BF). Sourafel Girma is grateful to the ESRC for financial support under its "National and international aspects of financial development" programme. 


\section{Introduction}

China has undergone dramatic economic changes since it started its economic reforms in 1979. Indeed, it has now emerged as a rapidly growing manufacturing base and exporting nation; an issue that has stirred much recent debate in the popular press as well as among academics. The process of opening up the Chinese economy has received a further boost since its accession to the World Trade Organisation (WTO) in 2001.

Economic reforms have had particular implications for Chinese State-owned enterprises (SOEs). From being the by far dominant form of enterprise in pre-reform China their importance has declined rapidly over the last two decades. For example, as Bajona and Chu (2004) show, the share of output produced by SOEs decreased from 78 percent in 1978 to 28 percent in 1999. Also, the SOE sector was shown to have been making net losses since the late 1990s. Still, the welfare of tens of millions of urban workers, the efficiency of the domestic banking sector and the generation of adequate state revenues all depend to a large extent on the success of SOEs. Given this development, a number of economists argue that without state subsidies, protection and easy access to bank credits, the majority of SOEs would be on the verge of collapse (e.g. Lin et al. 1998). Hence,

reforming SOEs in order to make them efficient to compete successfully on domestic and international markets is of utmost importance for sustained growth of the Chinese economy in particular in the light of the necessary adjustment of domestic policy to WTO rules. China's accession to WTO also means that Chinese SOEs are facing harder and harder budget constraints. Thus one can assume that SOEs are increasingly reacting to market signals. 
One way of improving efficiency and competitiveness in a firm is through innovative activity. ${ }^{1}$ Innovation allows firms to develop new processes to produce existing goods more efficiently or indeed develop new products (or differentiate existing ones) that allows it to expand sales and improve market performance. These two innovation activities are generally referred to as process and product innovation. We concern ourselves with the latter of these, product innovation. Specifically, our research question is to examine the role of firm level characteristics as well as inward foreign direct investment (FDI) for SOEs innovative activity. $^{2}$

FDI can impact on SOEs' activities in two ways. Firstly, directly at the level of the firm through injections of foreign capital, e.g., through acquisitions or joint ventures. In this case, our working assumption is that foreign capital participation at the firm level may bring with it transfer of knowledge from the foreign parent company which should stimulate innovation activity. Alternatively, even without knowledge transfer a capital inflow may reduce financial constraints and hence improve innovation. Secondly, FDI at the level of the industry can impact on SOEs innovation activity through potential competitive effects or spillovers. Competition from foreign multinationals can either stimulate domestic innovative activity or the effect can turn out to be negative, similar to the ideas discussed recently by Aghion et al. (2005). Furthermore, knowledge spillovers can have positive effects on innovative activity of SOEs. ${ }^{3}$

To investigate these issues we use a rich panel data set of some 30,000 state-owned enterprises (SOEs) in manufacturing industries for the period 1999 to 2003 . Our data, hence, allow us to have a first look at the post-WTO response of SOEs to multinational

\footnotetext{
${ }^{1}$ Of course, alternative responses at the firm level may be to reduce costs at given levels of output and technology ("downsizing"), or to shut down completely. We do not consider these issues here but focus on innovative activity in SOEs.

${ }^{2}$ Our paper is thus related to the study by $\mathrm{Hu}$ et al. (2005) who investigate the impact of domestic and foreign $\mathrm{R} \& \mathrm{D}$, and foreign direct investment on productivity of Chinese large and medium sized enterprises.

${ }^{3}$ This latter argument is similar to that made in the literature on "productivity spillovers" (e.g., Javorcik, 2004; Aitken and Harrison, 1999) that argues that domestic firms can "learn" from multinationals, e.g., through input-output linkages, demonstration effects or movement of workers.
} 
activities in China. We estimate an empirical model of SOEs product innovation activity where we take explicit account of endogeneity of regressors and allow for heterogeneous FDI effects. Our results show that inward FDI at the sector level impacts negatively on the innovative activity of SOEs. We also find that SOEs with foreign capital participation innovate more than other SOEs. Taking account of firm level heterogeneity we find that there is a positive effect of sector level FDI on SOEs which are already innovators, are $\mathrm{R} \& \mathrm{D}$ active, engage in labour training or are exporters.

The remainder of the paper is structured as follows. Section II provides a brief overview of the development of inward FDI in China. Section III describes the empirical approach, while Section IV introduces the data set and provides some summary statistics. Econometric results are discussed in Section V and Section VI concludes.

\section{An overview of FDI in China}

To motivate the empirical analysis, this section provides a brief overview of the trends of FDI flows into China over the past two and half decades. ${ }^{4}$ When the Chinese government initiated economic reforms in the late 1970s, FDI was only allowed in four designated Special Economic Zones (SEZs) ${ }^{5}$ and foreign investors were required to have local partners. However by 1986 the government started to implement further policies to attract FDI. Wholly foreign-owned enterprises were allowed for the first time, and exportoriented joint ventures and those employing advanced technology were encouraged through the provision of tax benefits.

As Figure 1 shows the various policies that are designed to attract FDI appear to have paid off. From nearly 0 in 1979 , the annual flow of FDI into China reached US\$ 53.51

\footnotetext{
${ }^{4}$ Some of the material in this section draws on Chen (1996, 1997), Lemoine (2000) and Wei (2003).

${ }^{5}$ The SEZs consisted of three in Guangdong province (Shenzhen, Zhuhai and Shantou) and Xiamen in Fujian Province.
} 
billion in 2003, leaving China to be ranked top FDI destination world-wide. The surge of FDI after 1992 had been mainly attributed to a wave of new policies of further economic liberalisation. Foreign investors were offered better opportunities to sell their products in the domestic market and allowed to invest into hitherto restricted sectors such as retail trade and finance. ${ }^{6}$

[Figure 1 here]

A noteworthy feature of FDI in China is that it is characterised by a very uneven regional distribution. During the period $1987-2000$, about $87 \%$ of cumulative FDI was located in the coastal regions (Wei, 2003). This is a reflection of the initial policy that restricted FDI to coastal regions and the proximity of those regions to Hong Kong and Taiwan, the main sources of foreign investment, especially at the initial stages of the economic reforms. Although western and central regions (where SOEs have significant presence) have started to gradually attract more and more foreign investors, the skewed distribution of FDI in favour of the eastern coastal regions has raised serious concerns that FDI might exacerbate existing regional disparities.

Given the huge potential of the Chinese market, it is perhaps surprising that only few countries are the major sources of inward investment. Between 1979 and 1991, Hong Kong accounted for nearly two-thirds of total FDI. Most of the investment from Hong Kong is export-oriented and concentrated in labour intensive sectors. During the same period, the share of Japanese and US FDI was $14 \%$ and $10 \%$ respectively. During the period 1992 to 1998 the average share of FDI from the US has declined to $8 \%$ and inward investment from the European Union countries accounted for less than $7 \%$ of total FDI. In general FDI from OECD countries tends to be directed to more capital-intensive sectors and is predominantly motivated by the desire to access the huge domestic market.

\footnotetext{
${ }^{6}$ However, it is worth noting that the devaluation of the Rembini also played an important part in the surge of FDI during this period.
} 


\section{Empirical approach}

Why would one expect the increased influx of FDI to have any effect on product innovation carried out by State-owned enterprises? Firstly, the influx of foreign capital can alleviate financial constraints which may hinder innovation. Also, foreign capital participation in an SOE may bring with it an inflow of technology. After all, in standard models of multinational enterprises (MNEs) they are assumed to have a "superior technology" compared to domestic firms (Markusen, 2002). Hence, a foreign capital inflow through an acquisition, joint venture or some other form of capital transfer may lead to the installation of the foreign technology in the SOE. Both of these processes could manifest themselves in increasing innovative activity. However, as multinationals generally undertake their innovative activity in the headquarters large inflows of foreign capital may actually be expected to reduce innovative activity, as these functions may be redirected to the parent company's home country.

At the level of the industry, the superior knowledge brought into the economy through FDI may leak to domestic firms through, e.g., worker movements, imitation etc, similar to the arguments made in the literature on productivity spillovers (e.g., Görg and Strobl, 2001). If domestic firms learn the better technology from MNEs then this may also lead to more innovation activity in the SOEs affected.

In addition to being potential generators of spillovers, multinationals will also affect the competitive landscape in the domestic economy, leading to an increase in competition for domestic firms. It is well known that competition affects innovative activity (e.g., Geroski, 1995, Blundell et al., 1999, Aghion et al., 2005) and we may therefore expect that an increasing influx of FDI will, through changes in competition, also impact on domestic

innovative activity. Aghion et al. (2005) argue theoretically and provide evidence that 
increasing competition is expected to discourage laggard firms from innovating, but may stimulate innovative activity in firms that are neck-on-neck in terms of technology with their competitors. Hence, the effect of FDI may depend on the "quality" of domestic firms: if they are laggards relative to multinationals then we would expect a negative competition effect. If, however, they are close to their multinational competitors we would expect increasing levels of FDI to stimulate innovation in domestic firms.

In our empirical model a SOE (indexed by $i$ ) either innovates at time $t$ with positive rate of innovation $\left(S_{i t}>1\right)$ or it does not $\left(S_{i t}=0\right)$. To determine the relationship between FDI and the rate of product innovation, defined as the share of innovation output $\mathrm{s}$ (that is products involving the use of new process innovation and novel technology) in total output, we formulate a Tobit model in terms of a latent variable model as follows:

$$
\begin{array}{ll}
S_{i t}^{*}=\beta^{\prime} X_{i t}+\gamma^{\prime} F D I_{i t-1}+D_{i t}+\varepsilon_{i t} \\
S_{i t}=0 & \text { if } S_{i t}^{*} \leq 0 \\
S_{i t}=S_{i t}^{*} & \text { if } S_{i t}^{*}>0
\end{array} .
$$

$X$ is a vector of firm level determinants of innovation which includes exporting intensity, $R \& D$ intensity, age, the ratio of employee training expenditure to total wage bills and the firm's market share within the three-digit industry. The choice of these firm level covariates is guided by theoretical considerations as well as existing empirical evidence (e.g. Crepon et al., 1998, Blundell et al., 1999, Jefferson and Huamao, 2004). On the other hand, FDI is a vector of lagged firm level and industry-region specific FDI indices, ${ }^{7}$ and $D$ consists of regional, industry and time dummies. A quadratic term of the firm level foreign participation variable is considered to allow for a more general non-linear relationship between foreign capital and innovation. The FDI variables are lagged for two reasons: (i) to allow for an adjustment period in the realisation of technology transfer and externalities, if any; and (ii) to mitigate potential endogeneity concerns.

\footnotetext{
${ }^{7}$ The variables in the econometric model will be described in more details the next section.
} 
Still, there are some variables in the above specification that are arguably contemporaneously determined with innovation and hence are potentially endogenous. One prominent example is $R \& D$ intensity as it is a major input into the product innovation process, and the choice of this input is likely to be correlated with factors that determine the firm's decision to innovate. Similar arguments can also be made regarding the potential endogeneity of market share, employee training and exporting. In order to deal with the problem of endogeneity, we use the instrumental variables technique for Tobit models due to Blundell and Smith (1986). We also formally test whether the assumption of endogeneity is borne out by the data at hand.

Lagged values of the potentially endogenous variables are used as instruments. In addition lagged firm debt (total bank loans/asset) and the share of the state sector in the industry and region are also used as extra instruments. The share of the state sector is a proxy for state dominance in the sector/region, and to the extent that firms in statedominated sectors/regions are less efficient (due to, for example, insufficient competitive stimulus) this variable is a relevant instrument for $R \& D$ activity or investment in human capital. Similarly, the level of debts or credit constraints is likely to affect product innovation through its effect on R\&D activity or human capital investment, and possibly exporting, and is therefore arguably a sensible instrument for the endogenous regressors. ${ }^{8}$

The estimation of Tobit models with endogenous regressors essentially involves two steps: ${ }^{9}$ (i) generate residual terms from linear regressions of each endogenous variable on the instrumental variables and all other exogenous regressors, and (ii) estimate a standard Tobit model by including the residual terms from step (i) in the list of covariates. The residual terms are correction terms for the endogeneity problem, and jointly statistically

\footnotetext{
${ }^{8} \mathrm{~A}$ test for the validity of the instruments is conducted in the next section.

${ }^{9}$ A one-step variant of this estimator involving stronger distributional assumptions is also available (see Newey, 1987). However, the estimator fails to attain convergence in our data. This type of convergence problem is frequently encountered when there are more than one endogenous regressors.
} 
significant coefficients can be taken as evidence in favour of the hypothesis that instrumented variables are indeed endogenous.

\section{Database description and variable construction}

We draw on the Annual Report of Industrial Enterprise Statistics compiled by the State Statistical Bureau of China, covering the population of state-owned enterprises and all other types of firms with annual turnover of over five million Renminbi (just above $\$ 600,000)$. The data set includes information on firm ownership structure, industry affiliation, geographic location, establishment year, employment, gross output, sales, product innovation (defined as the production of goods involving new technologies and new production processes), value added, net fixed assets, exports, $R \& D$ and employee training expenditures. The data available to us cover the period 1999 to 2003.

For reasons explained in the introduction, the focus of this paper is on the relationship between the innovation of state-owned enterprises and multinational activity in China. Foreign-owned multinationals are defined as enterprises with at least $25 \%$ share of foreign capital. However, state-owned enterprises have, in some instances, also minority ownership stakes (less than 25 percent) held by foreign owners. Our data set provides information on the extent of foreign capital participation at the level of the firm.10 This enables us to calculate the share of foreign ownership in the state owned enterprise (which will be less than $25 \%$ ) to identify the direct effects of FDI on the innovative activity of SOEs.

We use data on affiliates of foreign multinationals (i.e., those with at least $25 \%$ share of foreign capital) to calculate the variables on sector level FDI, which are defined

\footnotetext{
${ }^{10}$ The data set distinguishes between foreign capital participation in SOEs from Ethnic Chinese sources and other foreign sources.
} 
below. These variables allow us to examine the existence of intra-industry and interindustry effects, i.e., the indirect effects of FDI. In our data set, multinational enterprises which have owners from Hong Kong, Macao, or Taiwan are labelled Ethnic Chinese multinationals, whereas other MNEs (the majority of which are from OECD countries) are defined as foreign multinationals.

As has been pointed out in the recent literature on productivity spillovers from FDI, domestic firms can benefit from horizontal or vertical spillovers from FDI. Indeed, it is argued by, e.g., Javorcik (2004) that vertical spillovers may be more important than horizontal spillovers. Essentially, horizontal spillovers arise when domestic firms benefit from multinationals in the same industry through, e.g., demonstration effects, movement of labour or direct competition reducing X-inefficiency. Firms can also benefit through customer-supplier linkages with multinationals in different industry, this is termed vertical spillovers.

Accordingly, we firstly calculate a variable to capture horizontal spillovers, i.e., effects on domestic firms from multinationals operating in the same industry and region. The degree of horizontal FDI in industry $j$ at time $t$, say $H R F D I_{j t}$ is constructed as the share in total output accounted for by multinational companies in the same region, as is common in the literature. ${ }^{11}$ This measure of horizontal FDI and all other indices of FDI are constructed for each of the 180 three-digit industries within each of the 31 provinces of China. As a result, the FDI variables under consideration in this paper exhibit very good sample variability.

We also calculate two measures of foreign presence in backwardly and forwardly linked industries in line with the literature. To gauge the extent of backward linkages

\footnotetext{
${ }^{11}$ Total industry output includes output from foreign firms, SOEs, private firms and collectively owned enterprises.
} 
(spillovers received by domestic firms in upstream sectors), the backward measure of FDI for industry $j$ at time $t$ is computed as:

$$
B R F D I_{j t}=\sum_{\forall k \neq j} \alpha_{k j} H R F D I_{k t}
$$

where $\alpha_{k j}$ is the proportion of sector j's output supplied to industry $k$. It is assumed that the greater the proportion of output supplied to an industry with foreign multinational presence, the greater the degree of linkages between foreign and local firms. The index of sector-region specific FDI in upstream (forwardly linked) sectors is calculated similarly as

$$
F R F D I_{j t}=\sum_{\forall k \neq j} \beta_{k j} H R F D I_{k t}
$$

where $\beta_{k j}$ represents the proportion of sector $k$ 's output supplied to industry $j$. This measure captures the extent of forward linkages between local firms in downstream sectors and MNEs in upstream sectors. The information to construct the backward and forward linkage indices (that is the $\alpha$ s and $\beta s$ ) is obtained from the 1997 Input-Output Table of China published by the State Statistical Bureau.

To summarise, we hypothesise three potential sources of sector level FDI effects: horizontal, backward and forward. Each of these indices is further divided according to the geographic origin of the foreign investment (Ethnic Chinese versus Foreign multinationals). Beside these variables that capture the indirect effects of FDI on firm level innovation, we also include indicators of direct foreign participation at the level of the SOE, measured by the share of foreign capital in the SOE.

For 1999 and 2003, Table 1 gives the shares of state-owned enterprises (including those with less than 25 percent foreign capital participation) and foreign-owned multinational enterprises in the database across two digit industries. ${ }^{12}$ It is apparent that foreign-owned firms have significant presence in most industries. Industries particularly

\footnotetext{
${ }^{12}$ Recall, however, that the variables used in the analysis, as discussed previously, are defined at the three digit level.
} 
important to foreign investors include some high tech industries such as Electronic \& Telecommunications and Instruments \& Meters, but also more traditional manufacturing sectors such as Garments, Leather, and Timber Processing.

[Table 1 here]

Since the focus of this paper is on SOEs, we base our empirical analysis on those firms only. Hence, equation (1) will be estimated using data on some 30,000 SOEs for which adequate information is available. Table 2 provides some summary statistics of the variables used in the analysis.

\section{[Table 2 here]}

In Table 3 we report the pattern of product innovation development between 1999 and 2003 for SOEs across the two-digit industries. There are a number of noteworthy points. Firstly, the proportion of innovating firms has slightly declined over time in most sectors. However, the share of new product sales in total sales is quite significant and has risen in most sectors. Secondly, labour intensive sectors (e.g., food manufacturing and paper products) have in general the lowest proportion of innovators. However, export-competing labour intensive sectors (e.g., textile industry) exhibit a relatively large number of innovators. Finally, the product innovation intensity is remarkably similar across labour intensive (e.g. plastic products), capital-intensive (transport equipment) and technology intensive (e.g. medical and pharmaceutical products) sectors.

\section{[Table 3 here]}

\section{Discussion of the results}

Table 4 presents the estimations of the benchmark Tobit model using data for SOEs. column (1) shows results from a Tobit estimation treating all variables as exogenous, while column (2) relates to the estimation of an endogenous Tobit model as discussed in Section III. Note that the hypothesis of exogeneity (which is equivalent to testing the joint 
significance of the endogeneity-correction terms) is emphatically rejected, vindicating our approach to employ instrumental variable techniques in the estimations. Of course, the reliability of the endogenous Tobit hinges on the validity of instruments used. To our knowledge there are no formal tests of the validity of instruments within the context of these endogenous Tobit specifications. Nevertheless, in order to gauge the appropriateness of the instruments we estimate a linear instrumental variables model (using the same set of instruments as for the endogenous Tobit) and obtain a Sargan test statistic of the implied overidentifying restrictions. Reassuringly the test result, which is reported in column (2), suggests the validity of the instrumental variables. ${ }^{13}$

Turning to the estimates from the endogenous Tobit model in column (2) we find that $R \& D$ intensity exerts a positive and significant influence on the rate of product innovation. This is reassuring given that $R \& D$ intensity is a major input in the product innovation process. We also find that SOEs that invest in employee training have a higher propensity to innovate. This suggests that there may be complementarity between human capital investment and innovation as discussed by, for example, Redding (1996). Also, firms that enjoy higher market shares in their industry are more likely to engage in product innovation activity.

In contrast to Jefferson and Bai (2004), we find that older firms are more likely to engage in product innovation than their younger counterparts. This is consistent with the idea that older SOEs might be realising that their survival depends on the constant upgrading of their productive capabilities and changing their existing way of doing things. We also find a positive relationship between product innovation and exporting intensity.

\footnotetext{
${ }^{13}$ The results of the linear instrument variables regression are not reported here to save space. They are available from the authors upon request.
} 
This accords with Kraay (1999)'s view that amongst Chinese enterprises exporting is an indicator of superior performance. ${ }^{14}$

More closely related to the central issue of our paper, we find evidence that SOEs with some foreign capital participation are more likely to engage in product innovation. We, however, also find that the relationship between foreign capital participation and innovation is concave. This suggests that foreign capital participation increases innovation up to a critical value, after which the marginal effect of changes in foreign capital on innovative activity starts to decline. This probably reflects the fact that generally multinationals undertake their innovative activity in their headquarters (Markusen, 2002). Hence, while some foreign capital participation may bring with it knowledge transfer which initially increases innovative activity, further increases in the foreign ownership share may lead to innovation activity being relocated to the parent of the foreign owner abroad. However, according to the point estimates presented in column (2) of Table 4, the implied optimal value for foreign capital participation is about $48 \%$ (for foreign) and $53 \%$ (for Ethnic Chinese) respectively, well above the sample maximum of $25 \%{ }^{15}$

Turning our attention to the spillover effects of FDI, it is evident from Table 4 that the nature and extent of these effects vary according to the type of FDI under consideration. Specifically, we do not find any positive effects from backward or forward linkages between multinationals and domestic firms. In contrast, we find strong negative effects of horizontal Ethnic Chinese FDI on innovative activity. This suggests that the competition effect is important. In particular, with a view to the ideas developed by Aghion et al. (2005), our results are in line with the notion that SOEs are "laggards" relative to the

\footnotetext{
${ }^{14}$ However Eckaus (2004) argues that there exists a strong correlation between subsidies received by lossmaking SOEs and their export performance. This would appear to indicate that exporting amongst Chinese SOEs is not necessarily an indicator of superior performance.

${ }^{15}$ This indicates that innovative activity decreases once the firm is nearly majority-foreign owned, which is in line with our argument. Recall that once foreign participation exceeds $25 \%$ the firm is no longer classified as a domestically-owned SOE but as a foreign multinational.
} 
competition from multinationals and, hence, their innovative activity is stifled following increases in competition.

However, we also find moderate positive spillovers from foreign MNEs, which are generally more technologically advanced than Ethnic Chinese MNE, suggesting that for the average SOE, the competition effect resulting from foreign MNEs is more than compensated by technological externalities from those firms. However an important lesson that can be drawn from the literature on FDI spillovers is that average effects are seldom representative, and the incidence of positive spillovers from MNEs to indigenous enterprises is a function of the characteristics of the latter. For example, it is suggested that the extent of FDI spillovers is a function of domestic firms' ability to absorb technology (e.g. Girma, 2005).

\section{[Table 4]}

Accordingly, we explore the role of absorptive capacity in the present setting by interacting the FDI variables with alternative indicators of firm learning and competitive capabilities. Throughout, we work with a parsimonious model which excludes the vertical indices of FDI, as these were found to be jointly insignificant in our benchmark model. ${ }^{16}$ The indicators of absorptive/competitive capacity include past experience in product innovation, R\&D activity, labour training and exporting. As shown in Table 4, SOEs with more $\mathrm{R} \& \mathrm{D}$, labour training expenditure and exports are more likely to innovate. Hence, they may be less likely to be "laggards" and may actually be able to increase their innovative activity in the presence of increasing competition from FDI.

Table 5 shows the results of these regressions, where the interaction terms are generated by interacting the measures of horizontal FDI in turn with dummy variables for past product innovation (column 1), R\&D (column 2), labour training (column 3) and

\footnotetext{
${ }^{16}$ A test of the joint significance of the vertical variables in the benchmark model is reported in column (3) of Table 4. The vertical FDI variables also proved to be insignificant when interacted with the indicators of absorptive capacity.
} 
exporting (column 4). The results show that, controlling for absorptive capacity, there are strong unconditional negative effects of horizontal foreign presence (both Ethnic Chinese and foreign MNEs) on innovative activity of purely domestic. However, allowing for different coefficients of these variables conditional on the various indicators of absorptive capacity, we establish that there are statistically significant positive effects from horizontal foreign presence on the innovative activity by SOEs.

This can be interpreted in two ways: either, there are indeed positive knowledge spillovers from foreign multinationals to these types of firms, or the increase in competition stimulates innovative activity a la Aghion et al. (2005), indicating that these firms are not too far behind foreign multinationals in their industry. Either way, policy makers involved in the reform of SOEs should ensure that managers have the right incentives to make longterm investments in absorptive capacity development, rather than rely on unconditional and uniformly distributed spillovers from multinationals.

\section{[Table 5 here]}

Recall that our FDI variables are defined using data on foreign owned multinationals only, which are those firms with at least 25 percent foreign ownership. However, there are domestically-owned enterprises which have foreign capital participation of less than 25 percent which are not considered in this definition. Our argument for doing so is that while these firms benefit from foreign capital participation in terms of innovation (as shown in our estimations) there may be less potential for spillovers from them as foreign owners are unlikely to transfer the best technology. This is in line with the evidence by Javorcik and Spatareanu (2003) who find that, in Romania, foreign MNEs tend to transfer more technology to their wholly-owned projects than to those owned partially.

However, to allow for potential spillovers/competition from such domestic firms with less than 25 percent foreign capital participation and to check the robustness of our 
estimations thus far we use an alternative definition of sectoral FDI. Specifically, rather than defining horizontal FDI in industry $j$ at time $t$ (i.e. $H R F D I_{j t}$ ) as simply the proportion of output accounted for by multinational companies we exploit the richness of our data set and weigh the output of firms with foreign capital by the extent of their foreign participation, measured by the share of foreign capital at the level of the firm. Under this definition of sectoral FDI, firms that are classified as domestic but have some foreign capital will also (proportionally) contribute to aggregate output of the foreign sector. The results based on the local participation-weighted FDI indices are reported in Table 6. It is reassuring to note that the conditional and unconditional estimates exhibit the same pattern as observed in Table 5 both in terms of magnitude and statistical significance.

[Table 6 here]

In a further extension of the benchmark model, we consider whether the market orientation of multinationals (as opposed to their nationalities) matter for spillovers. The estimates from the endogenous Tobit model are given in Table 7. For SOEs with some experience in product innovation, R\&D activity, labour skill upgrading and exporting, the benefits from domestic market oriented FDI are more substantial than those from exportoriented FDI. This suggests the importance of market competition in spurring the innovative activities of SOEs which used to dominate the industrial landscape of China.

[Table 7 here]

\section{Conclusions}

The position of Chinese SOEs is distinct from other domestic enterprises operating in the economy, largely due to historical factors. For this reason, SOEs merit separate treatment when analysing firm behaviour in China. This paper investigates whether inward FDI, at the level of the firm and industry, has any impact on the rate of product innovation by the Chinese State owned enterprises (SOEs). To do so we use a rich firm level panel 
data set of some 30,000 SOEs covering the period 1999 to 2003 . Controlling for the endogeneity of the regressors and allowing for heterogeneous FDI effects, our results show that that foreign capital participation in an SOE is associated with higher innovative activity. Inward FDI in the sector has a negative effect on innovative activity in SOEs. However, there is a positive effect of FDI on SOEs that export, invest in human capital or $R \& D$, or have prior innovation experience. We also find that SOEs with internal $R \& D$ activity and human capital development are successful innovators.

We can interpret our findings in terms of the ideas developed by Aghion et al. (2005) on the role of competition for innovation. Poorly performing SOEs may be "laggards" and hence their innovative activity is discouraged due to increasing competition through FDI. By contrast, Chinese SOEs with higher level of absorptive capacity may be not too far behind foreign multinationals and, hence, their innovative activities are stimulated. This points to the conclusion that rather than just rely on unconditional FDI spillovers to improve domestic innovative activity, policy makers should focus more on getting the firm-level fundamentals right. 


\section{References}

Aghion, P., N. Bloom, R. Blundell, R. Griffith and P. Howitt (2005), Competition and innovation: An inverted U relationship, Quarterly Journal of Economics, May 2005, pp. 701-728.

Aitken, Brian J. and Ann E. Harrison (1999): "Do Domestic Firms Benefit from Direct Foreign Investment? Evidence from Venezuela", American Economic Review, Vol. 89, pp. 605-618.

Bajona, Claustre and Tianshu Chu (2004), China's WTO Accession and its effect on stateowned enterprises, East-West Center Working Papers, No. 70

Blundell, R., R. Griffith and J. van Reenen (1999), Market share, market value and innovation in a panel of British manufacturing firms, Review of Economic Studies, 66, 529554.

Chen, Chien-Husn (1996), "Regional determinants of foreign direct investment in mainland China", Journal of Economic Studies, 23(2), 18-7

Chen, Chunlai (1997), "Provincial characteristics and foreign direct investment location decision within China", Chinese Economy Research Unit Working Paper No. 97/16, University of Adelaide

Crepon, B., Duguet, E. and Mairesse (1998), "Research, innovation, and productivity: An econometric analysis at the firm level. NBER Working Paper 6696,

Eckaus, R.S (2004), "China's exports, subsidies to state owned enterprises and the WTO", MIT Department of Economics Working Paper 04-35.

Geroski, P. (1995), Market structure, corporate performance and innovative activity, Oxford: Oxford University Press.

Girma, S (2005). Absorptive capacity and productivity spillovers from FDI: a threshold regression analysis. Oxford Bulletin of Economics and Statistics, 67, 281-306.

Görg, Holger and Eric Strobl (2001): "Multinational Companies and Productivity Spillovers: A Meta-analysis”. Economic Journal, Vol. 111, pp. F723-F739.

Hu, A.G.Z, G.H. Jefferson and Q. Jinchang (2005). "R\&D and technology transfer: Firm level evidence from Chinese industry", Review of Economics and Statistics, forthcoming.

Jefferson, G.H. and Bai, H. (2004) "R\&D performance in Chinese industry". Economics of Innovation and New Technology, 13:1/2.

Javorcik, Beata S. (2004), "Does foreign direct investment increase the productivity of domestic firms? In search of spillovers through backward linkages", American Economic Review, 94, 605-627.

Javorcik, Beata S. and Spatareanu, Mariana (2003), "To Share or Not To Share: Does Local Participation Matter for Spillovers from Foreign Direct Investment?" World Bank Policy Research Working Paper 3118.

Kraay, A. (1999), "Exports and economic performance: Evidence from a panel of Chinese enterprises", Revue d'Economie du Développement, pp. 183-207. 
Lemoine, F. (2000), "FDI and the opening up of China's economy", CEPII Working Paper, No. 00-11, June

Lin, Justin.Y., Fang, Cai, Zhou, Li, 1998. Policy Burdens, and State-Owned Enterprise Reform. American Economic Review Papers and Proceedings, 88(2), 442-427.

Markusen, James R. (2002), Multinational firms and the theory of international trade, Cambridge MA: MIT Press.

Newey, W.K. (1987) "Efficient estimation of limited dependent variables models with endogenous explanatory variables". Journal of Econometrics 36, 231-250.

Redding, S. (1996), The low-skill, low-quality trap: Strategic complementarities between human capital and R \& D, Economic Journal, March 1996, 458-470.

Smith, R. J. and Blundell, R.W., "An exogeneity test for a simultaneous equation Tobit model with an application to labor supply". Econometrica, 54:4, 679-686.

Wei, Y. (2003), "Foreign Direct Investment in China", Lancaster University Management School Working Paper 2003/002 
Table 1:

Output share of state-owned (SOEs) and foreign-owned enterprises by industry :

\begin{tabular}{|c|c|c|c|c|c|c|}
\hline \multirow[t]{2}{*}{ Two-digit industry classification } & \multicolumn{2}{|c|}{ SOE } & \multicolumn{2}{|c|}{ FMNE } & \multicolumn{2}{|c|}{ HTM } \\
\hline & 1999 & 2003 & 1999 & 2003 & 1999 & 2003 \\
\hline 13-Food Processing & 0.519 & 0.391 & 0.117 & 0.165 & 0.12 & 0.118 \\
\hline 14-Food Production & 0.462 & 0.258 & 0.122 & 0.275 & 0.108 & 0.113 \\
\hline 15-Beverage Industry & 0.519 & 0.289 & 0.128 & 0.298 & 0.171 & 0.106 \\
\hline 16-Tobacco Processing & 0.474 & 0.432 & 0 & 0.007 & 0.072 & 0.027 \\
\hline 17-Textile Industry & 0.412 & 0.344 & 0.218 & 0.179 & 0.147 & 0.134 \\
\hline 18-Garments and Other Fibre Products & 0.325 & 0.26 & 0.267 & 0.319 & 0.203 & 0.189 \\
\hline 19-Leather, Furs, Down and Related Products & 0.341 & 0.376 & 0.275 & 0.258 & 0.182 & 0.131 \\
\hline 20-Timber Processing & 0.329 & 0.233 & 0.219 & 0.354 & 0.158 & 0.123 \\
\hline 21-Furniture Manufacturing & 0.453 & 0.29 & 0.141 & 0.177 & 0.155 & 0.307 \\
\hline 22-Papermaking and Paper Products & 0.409 & 0.542 & 0.106 & 0.33 & 0.133 & 0.107 \\
\hline 23-Printing and Record Medium Reproduction & 0.501 & 0.454 & 0.118 & 0.225 & 0.14 & 0.108 \\
\hline 24-Cultural, Educational and Sports Goods & 0.361 & 0.324 & 0.285 & 0.271 & 0.202 & 0.189 \\
\hline 25-Petroleum Refining and Coking & 0.621 & 0.331 & 0.068 & 0.101 & 0.07 & 0.173 \\
\hline 26-Raw Chemical Materials and Chemical Products & 0.439 & 0.383 & 0.173 & 0.14 & 0.12 & 0.126 \\
\hline 27-Medical and Pharmaceutical Products & 0.56 & 0.303 & 0.072 & 0.074 & 0.12 & 0.086 \\
\hline 28-Chemical Fibre & 0.451 & 0.314 & 0.168 & 0.269 & 0.221 & 0.135 \\
\hline 29-Rubber Products & 0.435 & 0.251 & 0.157 & 0.261 & 0.104 & 0.158 \\
\hline 30-Plastic Products & 0.472 & 0.351 & 0.213 & 0.207 & 0.145 & 0.14 \\
\hline 31-Nonmetal Mineral Products & 0.495 & 0.331 & 0.11 & 0.223 & 0.092 & 0.089 \\
\hline 32-Smelting and Pressing of Ferrous Metals & 0.461 & 0.473 & 0.115 & 0.103 & 0.096 & 0.22 \\
\hline 33-Smelting and Pressing of Nonferrous Metals & 0.547 & 0.435 & 0.085 & 0.169 & 0.211 & 0.116 \\
\hline 34-Metal Products & 0.449 & 0.374 & 0.169 & 0.219 & 0.121 & 0.119 \\
\hline 35-Ordinary Machinery & 0.515 & 0.42 & 0.153 & 0.143 & 0.088 & 0.101 \\
\hline 36-Special Purposes Equipment & 0.527 & 0.345 & 0.075 & 0.174 & 0.118 & 0.093 \\
\hline 37-Transport Equipment & 0.462 & 0.371 & 0.088 & 0.186 & 0.12 & 0.131 \\
\hline 39-Other Electronic Equipment & 0.467 & 0.313 & 0.175 & 0.137 & 0.184 & 0.196 \\
\hline 40-Electric Equipment and Machinery & 0.514 & 0.285 & 0.169 & 0.211 & 0.169 & 0.139 \\
\hline 41-Electronic and Telecommunications & 0.381 & 0.275 & 0.379 & 0.197 & 0.202 & 0.281 \\
\hline 42-Instruments and meters & 0.399 & 0.318 & 0.212 & 0.256 & 0.251 & 0.177 \\
\hline 43-Other Manufacturing & 0.486 & 0.356 & 0.255 & 0.272 & 0.176 & 0.131 \\
\hline
\end{tabular}

\section{Notes:}

i. Authors calculations based on the database used in this paper.

ii. The numbers preceding the industry description refer to the two-digit codes used by the State Statistical Bureau of China.

iii. HTM stands for foreign-invested enterprises from Hong Kong, Taiwan and Macao. FMNE represents subsidiaries of other foreign multinational enterprises.

iv. The residual share of output is due to non-state domestic enterprises (private firms and collective enterprises). 
Table 2:

Summary statistics

\begin{tabular}{|c|c|c|}
\hline Variables & Mean & Std. Dev. \\
\hline \multicolumn{3}{|l|}{ SOE level variables } \\
\hline Product innovation indicator & 0.1123 & 0.3157 \\
\hline $\begin{array}{l}\text { New product sales /total sales (innovators } \\
\text { only) }\end{array}$ & 0.2902 & 0.2723 \\
\hline Export sales / total sales & 0.0537 & 0.0936 \\
\hline Labour training expenditure/wage & 0.0059 & 0.0329 \\
\hline R\&D expenditure/ total sales & 0.0016 & 0.0235 \\
\hline Age & 27.1209 & 17.6688 \\
\hline Three-digit industry market share & 0.0010 & 0.0066 \\
\hline Share of foreign MNEs' capital* & 0.142 & 0.195 \\
\hline Share of Ethnic Chinese MNEs' capital* & 0.108 & 0.207 \\
\hline \multicolumn{3}{|c|}{ Sector-Region level variables } \\
\hline \multicolumn{3}{|l|}{ Horizontal FDI indices } \\
\hline Foreign Multinationals & 0.1113 & 0.1620 \\
\hline Ethnic Chinese & 0.0793 & 0.1351 \\
\hline \multicolumn{3}{|l|}{ Upstream FDI indices } \\
\hline Foreign Multinationals & 0.0007 & 0.0069 \\
\hline Ethnic Chinese & 0.0005 & 0.0044 \\
\hline \multicolumn{3}{|l|}{ Downstream FDI indices } \\
\hline Foreign Multinationals & 0.0005 & 0.0060 \\
\hline Ethnic Chinese & 0.0004 & 0.0029 \\
\hline
\end{tabular}

Note: The total number of observations used in the econometric analysis is 72706 . These are based on 29830 SOEs

(*) The average share of MNE capital in is calculated over SOEs with positive foreign capital only. 
Table 3:

Sectoral and temporal pattern of product innovation for SOEs

\begin{tabular}{|c|c|c|c|c|}
\hline \multirow[b]{2}{*}{ Two-digit industry classification } & \multicolumn{2}{|c|}{ Fraction of innovators } & \multicolumn{2}{|c|}{$\begin{array}{c}\text { New product sales/total } \\
\text { sales }\end{array}$} \\
\hline & 1999 & 2003 & 1999 & 2003 \\
\hline 13-Food Processing & 0.018 & 0.015 & 0.322 & 0.119 \\
\hline 14-Food Production & 0.038 & 0.031 & 0.215 & 0.36 \\
\hline 15-Beverage Industry & 0.071 & 0.052 & 0.213 & 0.171 \\
\hline 16-Tobacco Processing & 0.144 & 0.207 & 0.143 & 0.187 \\
\hline 17-Textile Industry & 0.164 & 0.122 & 0.264 & 0.249 \\
\hline 18-Garments and Other Fibre Products & 0.071 & 0.046 & 0.423 & 0.331 \\
\hline 19-Leather, Furs, Down and Related Products & 0.097 & 0.088 & 0.539 & 0.496 \\
\hline 20-Timber Processing & 0.021 & 0.021 & 0.469 & 0.371 \\
\hline 21-Furniture Manufacturing & 0.048 & 0.029 & 0.209 & 0.487 \\
\hline 22-Papermaking and Paper Products & 0.062 & 0.036 & 0.268 & 0.424 \\
\hline 23-Printing and Record Medium Reproduction & 0.012 & 0.007 & 0.375 & 0.471 \\
\hline 24-Cultural, Educational and Sports Goods & 0.085 & 0.067 & 0.251 & 0.433 \\
\hline 25-Petroleum Refining and Coking & 0.09 & 0.076 & 0.223 & 0.242 \\
\hline 26-Raw Chemical Materials and Chemical Products & 0.111 & 0.093 & 0.243 & 0.282 \\
\hline 27-Medical and Pharmaceutical Products & 0.193 & 0.157 & 0.265 & 0.369 \\
\hline 28-Chemical Fibre & 0.164 & 0.114 & 0.231 & 0.157 \\
\hline 29-Rubber Products & 0.207 & 0.18 & 0.252 & 0.235 \\
\hline 30-Plastic Products & 0.078 & 0.099 & 0.351 & 0.26 \\
\hline 31-Nonmetal Mineral Products & 0.047 & 0.045 & 0.283 & 0.312 \\
\hline 32-Smelting and Pressing of Ferrous Metals & 0.121 & 0.148 & 0.195 & 0.252 \\
\hline 33-Smelting and Pressing of Nonferrous Metals & 0.146 & 0.103 & 0.271 & 0.353 \\
\hline 34-Metal Products & 0.101 & 0.073 & 0.229 & 0.188 \\
\hline 35-Ordinary Machinery & 0.235 & 0.203 & 0.228 & 0.25 \\
\hline 36-Special Purposes Equipment & 0.196 & 0.173 & 0.271 & 0.324 \\
\hline 37-Transport Equipment & 0.192 & 0.195 & 0.311 & 0.306 \\
\hline 39-Other Electronic Equipment & 0.541 & 0.205 & 0.282 & 0.268 \\
\hline 40-Electric Equipment and Machinery & 0.217 & 0.295 & 0.269 & 0.428 \\
\hline 41-Electronic and Telecommunications & 0.363 & 0.267 & 0.398 & 0.386 \\
\hline 42-Instruments and meters & 0.336 & 0.02 & 0.32 & 0.452 \\
\hline 43-Other Manufacturing & 0.029 & 0.022 & 0.455 & 0.258 \\
\hline
\end{tabular}


Table 4:

FDI and Innovation : Benchmark model

\begin{tabular}{|c|c|c|c|}
\hline & (1) & (2) & (3) \\
\hline & $\begin{array}{l}\text { Exogenous Tobit } \\
\text { model }\end{array}$ & $\begin{array}{l}\text { Endogenous } \\
\text { Tobit model }\end{array}$ & $\begin{array}{c}\text { Restricted } \\
\text { endogenous Tobit } \\
\text { model }\end{array}$ \\
\hline \multirow[t]{2}{*}{ Export intensity } & 0.123 & 0.124 & 0.124 \\
\hline & $(0.041)^{* * *}$ & $(0.075)^{*}$ & $(0.075)^{*}$ \\
\hline \multirow[t]{2}{*}{ R\&D intensity } & 0.658 & 0.893 & 0.894 \\
\hline & $(0.096) * * *$ & $(0.134)^{* * *}$ & $(0.134)^{* * *}$ \\
\hline \multirow[t]{2}{*}{ Labour training } & 0.352 & 0.509 & 0.507 \\
\hline & $(0.084) * * *$ & $(0.143)^{* * *}$ & $(0.143)^{* * *}$ \\
\hline \multirow[t]{2}{*}{ Market share } & 4.831 & 14.141 & 14.146 \\
\hline & $(0.332)^{* * *}$ & $(0.807) * * *$ & $(0.807) * * *$ \\
\hline \multirow[t]{2}{*}{ Age } & 0.006 & 0.006 & 0.006 \\
\hline & $(0.0001)^{* * *}$ & $(0.0001) * * *$ & $(0.0001)^{* * *}$ \\
\hline \multicolumn{4}{|l|}{ Firm level FDI } \\
\hline \multirow[t]{2}{*}{ Foreign MNEs } & 2.319 & 2.003 & 2.005 \\
\hline & $(0.226) * * *$ & $(0.228)^{* * *}$ & $(0.228) * * *$ \\
\hline \multirow[t]{2}{*}{ Foreign Squared } & -2.352 & -2.088 & -2.090 \\
\hline & $(0.388)^{* * *}$ & $(0.390) * * *$ & $(0.390) * * *$ \\
\hline \multirow[t]{2}{*}{ Ethnic Chinese MNEs } & 1.700 & 1.624 & 1.617 \\
\hline & $(0.281)^{* * *}$ & $(0.281)^{* * *}$ & $(0.281)^{* * *}$ \\
\hline \multirow[t]{2}{*}{ Ethnic Chinese squared } & -1.612 & -1.526 & -1.516 \\
\hline & $(0.461)^{* * *}$ & $(0.460) * * *$ & $(0.460) * * *$ \\
\hline \multicolumn{4}{|l|}{ Horizontal FDI spillovers } \\
\hline \multirow[t]{2}{*}{ Foreign MNEs } & 0.005 & $0.037 *$ & 0.038 \\
\hline & $(0.023)$ & $(0.020)$ & $(0.021)^{*}$ \\
\hline \multirow[t]{2}{*}{ Ethnic Chinese MNEs } & -0.225 & -0.194 & -0.196 \\
\hline & $(0.033) * * *$ & $(0.032)^{* * *}$ & $(0.032)^{* * *}$ \\
\hline \multicolumn{4}{|l|}{ Forward FDI spillovers } \\
\hline \multirow[t]{2}{*}{ Foreign MNEs } & 0.014 & 0.021 & \\
\hline & $(0.608)$ & $(0.610)$ & \\
\hline \multirow[t]{2}{*}{ Ethnic Chinese MNEs } & -0.546 & -0.472 & \\
\hline & $(1.046)$ & $(1.051)$ & \\
\hline \multicolumn{4}{|l|}{ Backward FDI spillovers } \\
\hline \multirow[t]{2}{*}{ Foreign MNEs } & -1.280 & -1.231 & \\
\hline & $(0.765)^{*}$ & $(0.760)$ & \\
\hline \multirow[t]{2}{*}{ Ethnic Chinese MNEs } & 0.381 & 0.130 & \\
\hline & $(1.326)$ & $(1.330)$ & \\
\hline Exogeneity test (p-value) & & 0.02 & 0.02 \\
\hline Observations & 72706 & 72706 & 72706 \\
\hline $\begin{array}{l}\text { p-value from validity of } \\
\text { instruments test }\end{array}$ & & 0.282 & \\
\hline $\begin{array}{l}\text { Test of joint insignificance } \\
\text { of vertical FDI variables }\end{array}$ & & & $\begin{array}{c}\text { Chi2(4) }=3.22 \\
\text { p-value }=0.521\end{array}$ \\
\hline
\end{tabular}

Notes:

(i) Dependent variable: share of innovation output in total output

(ii) Standard errors in parentheses

(iii) significant at $10 \%$; $*$ significant at $5 \%$; *** significant at $1 \%$

(iv) All regressions include industry, region and time dummies. 
Table 5

FDI and Innovation: The role of absorptive capacity

\begin{tabular}{|c|c|c|c|c|}
\hline & $(1)$ & $(2)$ & (3) & (4) \\
\hline \multirow[t]{2}{*}{ Export intensity } & 0.126 & 0.112 & 0.131 & -0.134 \\
\hline & $(0.069)^{*}$ & $(0.064)^{*}$ & $(0.075)^{*}$ & $(0.079)^{*}$ \\
\hline \multirow[t]{2}{*}{ R\&D intensity } & 0.705 & 0.344 & 0.803 & 0.863 \\
\hline & $(0.121)^{* * *}$ & $(0.140)^{* *}$ & $(0.134)^{* * *}$ & $(0.133)^{* * *}$ \\
\hline \multirow[t]{2}{*}{ Labour training } & 0.380 & 0.324 & 0.124 & 0.481 \\
\hline & $(0.132)^{* * *}$ & $(0.147)^{* *}$ & $(0.158)$ & $(0.144)^{* * *}$ \\
\hline \multirow[t]{2}{*}{ Market share } & 10.868 & 13.017 & 13.741 & 13.667 \\
\hline & $(0.700)^{* * *}$ & $(0.790)^{* * *}$ & $(0.800)^{* * *}$ & $(0.803)^{* * *}$ \\
\hline \multirow[t]{2}{*}{ Age } & 0.003 & 0.005 & 0.005 & 0.006 \\
\hline & $(0.0001)^{* * *}$ & $(0.0001)^{* * *}$ & $(0.0001)^{* * *}$ & $(0.0001)^{* * *}$ \\
\hline \multicolumn{5}{|l|}{ Firm level FDI } \\
\hline \multirow[t]{2}{*}{ Foreign MNEs } & 1.197 & 1.711 & 1.875 & 1.915 \\
\hline & $(0.210) * * *$ & $(0.224) * * *$ & $(0.228) * * *$ & $(0.227) * * *$ \\
\hline \multirow[t]{2}{*}{ Foreign MNEs squared } & -1.451 & -1.859 & -1.954 & -2.008 \\
\hline & $(0.365)^{* * *}$ & $(0.382)^{* * *}$ & $(0.391)^{* * *}$ & $(0.388)^{* * *}$ \\
\hline \multirow[t]{2}{*}{ Ethnic Chinese MNEs } & 1.158 & 1.339 & 1.554 & 1.490 \\
\hline & $(0.265)^{* * *}$ & $(0.273)^{* * *}$ & $(0.278) * * *$ & $(0.279)^{* * *}$ \\
\hline \multirow[t]{2}{*}{ Ethnic Chinese squared } & -1.324 & -1.127 & -1.375 & -1.393 \\
\hline & $(0.447)^{* * *}$ & $(0.438)^{* *}$ & $(0.450)^{* * *}$ & $(0.457)^{* * *}$ \\
\hline \multicolumn{5}{|l|}{$\begin{array}{l}\text { Unconditional horizontal } \\
\text { FDI spillovers }\end{array}$} \\
\hline \multirow[t]{2}{*}{ Foreign MNEs } & -1.046 & -0.274 & -0.348 & -0.768 \\
\hline & $(0.039)^{* * *}$ & $(0.028)^{* * *}$ & $(0.035)^{* * *}$ & $(0.068)^{* * *}$ \\
\hline \multirow[t]{2}{*}{ Ethnic Chinese MNEs } & -1.239 & -0.407 & -0.510 & -0.718 \\
\hline & $(0.056)^{* * *}$ & $(0.037) * * *$ & $(0.048) * * *$ & $(0.090) * * *$ \\
\hline \multicolumn{5}{|l|}{$\begin{array}{l}\text { Horizontal FDI spillovers * } \\
\text { conditioning variable }\end{array}$} \\
\hline \multirow[t]{2}{*}{ Foreign MNEs } & 2.147 & 0.975 & 0.633 & 0.895 \\
\hline & $(0.046)^{* * *}$ & $(0.040)^{* * *}$ & $(0.039)^{* * *}$ & $(0.068)^{* * *}$ \\
\hline \multirow[t]{2}{*}{ Ethnic Chinese MNEs } & 2.567 & 0.835 & 0.554 & 0.589 \\
\hline & $(0.069)^{* * *}$ & $(0.063)^{* * *}$ & $(0.057)^{* * *}$ & $(0.093)^{* * *}$ \\
\hline Exogeneity test (p-test) & 0.04 & 0.04 & 0.04 & 0.02 \\
\hline Conditioning dummy variable & $\begin{array}{l}\text { Product } \\
\text { innovation }\end{array}$ & $R \& D$ & $\begin{array}{l}\text { Labour } \\
\text { training }\end{array}$ & Exporting \\
\hline Observations & 72706 & 72706 & 72706 & 72706 \\
\hline
\end{tabular}

Notes;

(i) Dependent variable: share of innovation output in total output

(ii) Standard errors in parentheses

(iii) significant at $10 \%$; $* *$ significant at $5 \%$; $* * *$ significant at $1 \%$

(iv) All regressions include industry, region and time dummies 
Table 6

Robustness check:

Alternative definition of horizontal FDI

\begin{tabular}{|c|c|c|c|c|}
\hline & $(1)$ & $(2)$ & (3) & $(4)$ \\
\hline \multirow[t]{2}{*}{ Export intensity } & 0.137 & 0.100 & 0.124 & -0.032 \\
\hline & $(0.071)^{*}$ & $(0.055)^{*}$ & $(0.075)^{*}$ & $(0.077)$ \\
\hline \multirow[t]{2}{*}{ R\&D intensity } & 0.811 & 0.587 & 0.858 & 0.891 \\
\hline & $(0.124)^{* * *}$ & $(0.135)^{* * *}$ & $(0.133)^{* * *}$ & $(0.133)^{* * *}$ \\
\hline \multirow[t]{2}{*}{ Labour training } & 0.452 & 0.401 & 0.191 & 0.476 \\
\hline & $(0.141)^{* * *}$ & $(0.147)^{* * *}$ & $(0.152)$ & $(0.144)^{* * *}$ \\
\hline \multirow[t]{2}{*}{ Market share } & 10.772 & 12.802 & 13.783 & 13.946 \\
\hline & $(0.743)^{* * *}$ & $(0.796)^{* * *}$ & $(0.797)^{* * *}$ & $(0.799)^{* * *}$ \\
\hline \multirow[t]{2}{*}{ Age } & 0.004 & 0.006 & 0.006 & 0.006 \\
\hline & $(0.0001)^{* * *}$ & $(0.0002)^{* * *}$ & $(0.0001)^{* * * *}$ & $(0.0001)^{* * *}$ \\
\hline \multicolumn{5}{|l|}{ Firm level FDI } \\
\hline \multirow[t]{2}{*}{ Foreign MNEs } & 1.447 & 1.830 & 1.975 & 1.994 \\
\hline & $(0.220)^{* * *}$ & $(0.225)^{* * *}$ & $(0.230)^{* * *}$ & $(0.228)^{* * *}$ \\
\hline \multirow[t]{2}{*}{ Foreign MNEs squared } & -1.778 & -1.982 & -2.092 & -2.104 \\
\hline & $(0.390) * * *$ & $(0.382) * * *$ & $(0.397) * * *$ & $(0.390) * * *$ \\
\hline \multirow[t]{2}{*}{ Ethnic Chinese MNEs } & 1.064 & 1.509 & 1.509 & 1.505 \\
\hline & $(0.269)^{* * *}$ & $(0.277)^{* * *}$ & $(0.280)^{* * *}$ & $(0.280)^{* * *}$ \\
\hline \multirow[t]{2}{*}{ Ethnic Chinese squared } & -1.102 & -1.352 & -1.358 & -1.431 \\
\hline & $(0.443) * *$ & $(0.451)^{* * *}$ & $(0.458)^{* * *}$ & $(0.460)^{* * *}$ \\
\hline \multicolumn{5}{|l|}{$\begin{array}{c}\text { Unconditional horizontal } \\
\text { FDI spillovers } \\
\end{array}$} \\
\hline \multirow[t]{2}{*}{ Foreign MNEs } & -0.987 & -0.207 & -0.299 & -0.559 \\
\hline & $(0.044) * * *$ & $(0.029) * * *$ & $(0.039) * * *$ & $(0.081)^{* * *}$ \\
\hline \multirow[t]{2}{*}{ Ethnic Chinese MNEs } & -1.034 & -0.309 & -0.422 & -0.837 \\
\hline & $(0.053)^{* * *}$ & $(0.037)^{* * *}$ & $(0.049)^{* * *}$ & $(0.117)^{* * *}$ \\
\hline \multicolumn{5}{|l|}{$\begin{array}{c}\text { Horizontal FDI spillovers * } \\
\text { conditioning variable }\end{array}$} \\
\hline \multirow[t]{2}{*}{ Foreign MNEs } & 2.335 & 0.935 & 0.594 & 0.683 \\
\hline & $(0.057)^{* * *}$ & $(0.050)^{* * *}$ & $(0.046)^{* * *}$ & $(0.083)^{* * *}$ \\
\hline \multirow[t]{2}{*}{ Ethnic Chinese MNEs } & 2.329 & 0.872 & 0.617 & 0.850 \\
\hline & $(0.069) * * *$ & $(0.062) * * *$ & $(0.059) * * *$ & $(0.120)^{* * *}$ \\
\hline Exogeneity test (p-test) & 0.10 & 0.06 & 0.03 & 0.02 \\
\hline Conditioning dummy variable & $\begin{array}{l}\text { Product } \\
\text { innovation }\end{array}$ & $\mathrm{R} \& \mathrm{D}$ & $\begin{array}{l}\text { Labour } \\
\text { training }\end{array}$ & Exporting \\
\hline Observations & 72706 & 72706 & 72706 & 72706 \\
\hline
\end{tabular}

Notes;

(v) Dependent variable: share of innovation output in total output

(vi) Standard errors in parentheses

(vii) significant at 10\%; ** significant at 5\%; *** significant at $1 \%$

(viii) All regressions include industry, region and time dummies

(ix) Definition of horizontal FDI includes domestic enterprises with less than 25 percent foreign ownership, weighted by share of foreign capital at firm level 
Table 7

Domestic innovation and the market orientation of FDI:

\begin{tabular}{|c|c|c|c|c|}
\hline & (1) & (2) & (3) & (4) \\
\hline \multirow[t]{2}{*}{ Export intensity } & 0.125 & 0.111 & 0.127 & 0.148 \\
\hline & $(0.069)^{*}$ & $(0.054)^{*}$ & $(0.075)^{*}$ & $(0.079)^{*}$ \\
\hline \multirow[t]{2}{*}{ R\&D intensity } & 0.671 & 0.369 & 0.808 & 0.877 \\
\hline & $(0.120)^{* * *}$ & $(0.140)^{* * *}$ & $(0.134) * * *$ & $(0.133)^{* * *}$ \\
\hline \multirow[t]{2}{*}{ Labour training } & 0.381 & 0.313 & 0.108 & 0.482 \\
\hline & $(0.131) * * *$ & $(0.147)^{* *}$ & $(0.159)$ & $(0.144) * * *$ \\
\hline \multirow[t]{2}{*}{ Market share } & 10.819 & 12.932 & 13.689 & 13.600 \\
\hline & $(0.697)^{* * *}$ & $(0.791)^{* * *}$ & $(0.800)^{* * *}$ & $(0.803)^{* * *}$ \\
\hline \multirow[t]{2}{*}{ Age } & 0.003 & 0.005 & 0.005 & 0.006 \\
\hline & $(0.0001)^{* * *}$ & $(0.0001)^{* * *}$ & $(0.0001)^{* * *}$ & $(0.0001)^{* * *}$ \\
\hline \multicolumn{5}{|l|}{ Firm level FDI } \\
\hline \multirow[t]{2}{*}{ Foreign MNEs } & 1.198 & 1.782 & 1.920 & 1.957 \\
\hline & $(0.209) * * *$ & $(0.224) * * *$ & $(0.228)^{* * *}$ & $(0.227)^{* * *}$ \\
\hline \multirow[t]{2}{*}{ Foreign MNEs squared } & -1.455 & -1.955 & -2.006 & -2.059 \\
\hline & $(0.363)^{* * *}$ & $(0.383)^{* * *}$ & $(0.392)^{* * *}$ & $(0.389) * * *$ \\
\hline \multirow[t]{2}{*}{ Ethnic Chinese MNEs } & 1.213 & 1.318 & 1.538 & 1.465 \\
\hline & $(0.261)^{* * *}$ & $(0.274)^{* * *}$ & $(0.278)^{* * *}$ & $(0.280)^{* * *}$ \\
\hline \multirow[t]{2}{*}{ Ethnic Chinese squared } & -1.339 & -1.111 & -1.366 & -1.381 \\
\hline & $(0.439) * * *$ & $(0.439) * *$ & $(0.451)^{* * *}$ & $(0.460) * * *$ \\
\hline \multicolumn{5}{|l|}{$\begin{array}{c}\text { Unconditional horizontal } \\
\text { FDI spillovers } \\
\end{array}$} \\
\hline \multirow[t]{2}{*}{ Domestic-oriented FDI } & -1.248 & -0.349 & -0.436 & -0.878 \\
\hline & $(0.040)^{* * *}$ & $(0.028) * * *$ & $(0.035)^{* * *}$ & $(0.070)^{* * *}$ \\
\hline \multirow[t]{2}{*}{ Export-oriented FDI } & -0.825 & -0.269 & -0.340 & -0.511 \\
\hline & $(0.059) * * *$ & $(0.042)^{* * *}$ & $(0.056)^{* * *}$ & $(0.099) * * *$ \\
\hline \multicolumn{5}{|l|}{$\begin{array}{c}\text { Horizontal FDI spillovers } * \\
\text { conditioning variable }\end{array}$} \\
\hline \multirow[t]{2}{*}{ Domestic-oriented FDI } & 2.681 & 1.093 & 0.720 & 0.957 \\
\hline & $(0.048)^{* * *}$ & $(0.042) * * *$ & $(0.039) * * *$ & $(0.071) * * *$ \\
\hline \multirow[t]{2}{*}{ Export-oriented FDI } & 1.462 & 0.596 & 0.377 & 0.458 \\
\hline & $(0.071)^{* * *}$ & $(0.070)^{* * *}$ & $(0.065)^{* * *}$ & $(0.103)^{* * *}$ \\
\hline Exogeneity test (p-test) & 0.05 & 0.06 & 0.04 & 0.02 \\
\hline Conditioning dummy variable & $\begin{array}{l}\text { Product } \\
\text { innovation }\end{array}$ & $\mathrm{R} \& \mathrm{D}$ & $\begin{array}{l}\text { Labour } \\
\text { training }\end{array}$ & Exporting \\
\hline Observations & 72706 & 72706 & & 72706 \\
\hline
\end{tabular}

Notes;

(i) Dependent variable: share of innovation output in total output

(ii) Standard errors in parentheses

(iii) significant at $10 \%$; $*$ significant at $5 \%$; $* * *$ significant at $1 \%$

(iv) All regressions include industry, region and time dummies 


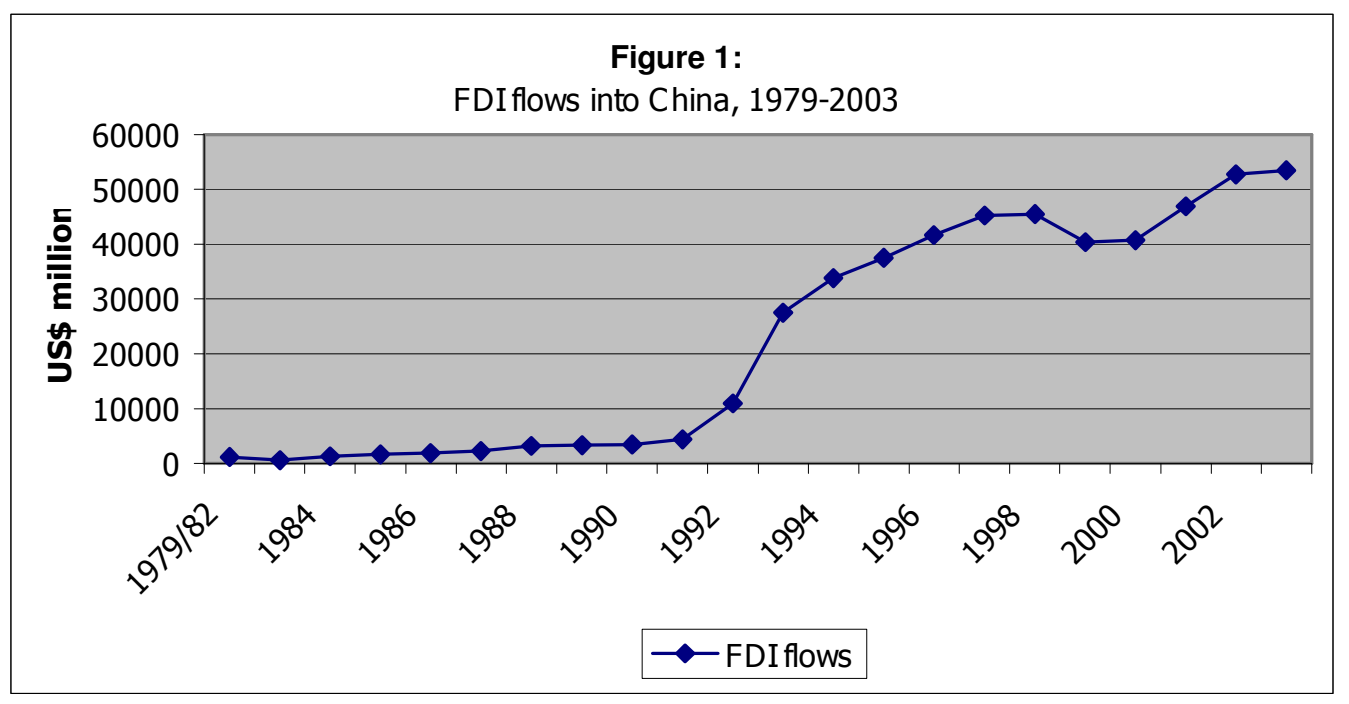

Data Source: China Statistical Yearbook, various issues 